\title{
Introduction to Special Issue of Sociological Review on 'Futures in Question: Theories, Methods, Practices'
}

\section{Rebecca Coleman (Sociology Department, Goldsmiths, University of London) and Richard Tutton (Department of Sociology, Lancaster University)}

'The future' has interested philosophers, social theorists, artists, scientists, designers, policy makers, activists and civil rights leaders for many years. While politicians vying for election will often invoke the future as a better time (e.g. Obama's 2008 'Hope' election campaign, or New Labour’s 1997 ‘Things Can Only Get Better’ election anthem), writers from Barbara Adam (2004, 2011, Adam and Groves 2007), to Franco 'Bifo' Berardi (2011) to Slavoj Žižek (2011) and John Urry $(2011,2016)$ challenge whether this will indeed be the case. Urry (2010: 1) argues that 'the twentieth century has left a bleak legacy for the new century, with a very limited range of possible future scenarios'. Indeed, as we drafted this introductory text, the World Meteorological Association reported that 'we will soon be living with globally averaged $\mathrm{CO} 2$ levels above 400 parts per million as a permanent reality' (Vaughan, 2015), contributing further to climate change and 'mak[ing] the planet more dangerous and inhospitable for future generations' (World Meterological Association 2015). Furthermore, in the current climate of austerity (at least in the UK), economists and activists question the notion of ongoing growth, and commentators from radically different perspectives argue that today's young people are left with 'no future' (Giroux 2011, Willetts 2011, Clegg 2011). Culturally, Berardi argues that since the middle of the last century, Western imagination turned decidedly dystopian and utopias are rejected as dangerous illusions (see also Levitas 2011). However, during the past two decades at least, it is also the case that social scientists have emphasized the hopefulness invested in biotechnology and biomedical advances to 
bring cures for human disease and argued that biology is no longer fate but an open future to be worked upon by 'biological citizens' (Rose and Novas 2005; for an alternative view, see Brown and Nettleton, this volume). What these distinct, diverse and non-exhaustive examples indicate, then, is that an engagement with and interrogation of 'the future' is certainly a timely undertaking for social scientists.

This special issue emerged out of a conference that we organized at Goldsmiths, London in September 2014, with the title 'Futures in Question'. The conference itself was the final event in an ESRC Research Seminar Series on 'Austerity Futures: Imagining and Materialising the Future in an "Age of Austerity" (2012-14). By involving a range of scholars from the social sciences, arts and humanities, our aim was to explore the contours of 'the future' in the current context of multiple financial, ecological and political crises. Taking up a call from Nik Brown and Mike Michael (2003: 4), both contributors to this volume, we wanted to 'shift the analytical emphasis from looking into the future to looking at the future' - that is, to 'engage with the future as an analytical object, and not simply a neutral temporal space into which objective expectations can be projected'.

In engaging with and seeking to contribute to social scientific work on futures, the special issue shows that after many years during which temporality and the future have been examined by the social sciences (in Western intellectual debates at least, as we discuss below), recently there has been a revitalisation of interest in the future (see also Schultz 2015, ISA 2016). As indicated above, Barbara Adam's contribution to social theories of time (e.g. 1994, 1995, 2004) and futures more specifically (e.g. 2009, 2010, Adam and Groves 2007, http://www.futurematterscollective.com) has been particularly notable (e.g. 1994, 1995, 2004). John Urry's work, in Climate Change and Society (2011), Societies Beyond Oil: Oil 
Dregs and Social Futures (2013) and What is the Future? (2016) especially, has also been important.

We might also look to a range of other work on futures, including science and technology studies (STS) and geography. Temporality and futures have emerged as significant in understanding processes of securitisation including pre-empting and anticipating future terrorist threats (e.g. Anderson 2009, 2010), and monitoring and securing borders (e.g. Amoore 2013). Louise Amoore's work on the emergence of a politics of possibility challenges models of predicting the future through calculations of risk probability, and instead incorporate [s] the very unknowability and profound uncertainty of the future into imminent decision' (Amoore 2013: 9). Such work on anticipation and possibility problematises an understanding of time as flowing straightforwardly and linearly towards the future. Pre-emptive and anticipatory securitisation, for example, 'make the future present' (Anderson 2010: 230) through the staging of training events that aim to ensure that a particular threat in the future does not take place (see also Massumi 2005). Indeed, Amoore argues that the politics of possibility 'acts not to prevent the playing out of a particular course of events on the basis of past data tracked forward into probable futures but to preempt an unfolding and emergent event in relation to an array of possible projected futures' (2013: 9). In the context of digital media and big data, it has become necessary to examine the temporalities and futures that may be produced. Patricia Ticineto Clough et al argue that big data algorithms operate not so much via a pre-emptive logic as a prehensive one, where they attune to emergence and novelty to grasp a series of possibilities; 'A house is no longer a home, but rather a forecast of possible futures' from which moving and distinctive patterns may be generated (for profit, better understanding of behaviour, and so on; Clough et al 2015: 159, see also Clough 2014, Hansen 2015 and for a focus on speculative finance, see Adkins, this volume). 
The timing of our conference and, subsequently, this special issue, has also been apposite because 2014-15 marked an interesting anniversary in what we might think of as the cultural history of the future. Fifty years earlier, the New York World's Fair opened for the 1964 summer season. The backstory of how Robert Moses, New York City’s Planning Officer, came to organize this event without the approval of the World Fairs Association does not concern us here (see Samuel 2007 for an account), except to note that this Fair placed US business and its visions of the future at the centre much more than previous ones did. Firms such as General Motors, IBM, Bell Telephone, and Disney spent three hundred million dollars constructing pavilions in which to project their representations and simulations of the future. These included Martian colonies, lunar bases, undersea aquatic tourist resorts, self-driving cars, domestic robots, and videophones. The science fiction author Isaac Asimov visited the World's Fair and the New York Times commissioned him to write about what he saw and to imagine the world fifty years into the future. He observed that: 'what is to come, through the [New York] fair's eyes at least, is wonderful. The direction in which man [sic] is traveling is viewed with buoyant hope' (Asimov 1964). Although he struck a note of caution about population growth, Asimov's view of the future was also a positive one in which human technological ingenuity would shine through, solving any problems posed by the increasing number of people and their consumption of resources.

The New York World's Fair also featured in the 2015 Hollywood film Tomorrowland, produced by Disney Studios. As a simulation of the future in the present, in the film the Fair becomes a gateway into another time and space. In fact, film provides an interesting way to frame our questioning of contemporary futures. The screen writers of Tomorrowland engage with the future in an entertaining and spectacular way. Through the visual power of CGI, 
the film brings to the twenty-first century audience an image of a future first constructed at Disneyland in 1955. It is an image of the city from which rockets take off on interplanetary missions, of cars moving freely along smoothly paved roads, towers of glass, set in an environment of clean air and sunshine, and surrounded by corn fields.

Set in the context of climate change, threats of terrorism, and the implied closure of NASA (poignantly symbolizing a retreat from that promised future of human interplanetary expansion), the film conjures up Tomorrowland as the future that never was - out of time, out of place, constructed but never inhabited. The film's message is one of salvation found in re-embracing the promise of technoscience and spectacularly resurrects what Berardi (2011) calls the 'progressive myth of the future'. One interesting feature is the way that in the film, representations of the future are shown to be performative: we - the audience - are told that we have come to consume and to enjoy consuming dystopian images of the future so much that we now see the future, as Berardi suggests, as an 'unavoidable catastrophe that we cannot oppose in any way' (Berardi 2011: 126). Through our very actions, we bring into being our own destruction: making real the dark images of the future. Only by remembering the future that never was can we avoid our fate.

The fate of Tomorrowland, however was one of box office failure: cinema goers in the US and China may not have been persuaded by its vision. However, Tomorrowland remains a fascinating cultural representation. Following Mark Fisher's book Ghosts of my Life: Writings on Depression, Hauntology and Lost Futures (2014), we might think of Tomorrowland as a spectral future. Fisher draws on Hägglund's discussion of the figure of the spectre as marking both what is no longer there and what is not yet there (see Fisher 2014: 19). This leads him to argue that we are haunted by what has gone and is in the past and by what might yet happen - both have what Fisher calls an 'effective virtuality' (Fisher 2014: 19); to 
which we might add that they have an affective dimension too, invoking melancholia, dread, anticipation, desire. Arguably, Tomorrowland somehow combines both aspects: it is both not yet and no longer: it is a lost future of the twentieth century that haunts contemporary technoscientific imaginaries.

Set against this hauntology of the past myths of progressive futures, there are what Evan Calder Williams (2011) calls the 'apocalyptic fantasies of late capitalism.' These fantasies, he argues, have gained cultural traction since the late 1960s. Williams (2011:4) refers to a 'structure of feeling and a repetition of content wound through the cultural production of certain periods that is fundamentally apocalyptic [...] Now is one of those times'. In this respect, we note that in contrast to Tomorrowland, the rebooted Mad Max episode Mad Max: Fury Road achieved an altogether much more impressive critical and popular reception, presenting instead a post-apocalyptic future, with the tagline, 'the future belongs to the mad'.

Usefully, Williams leads us to see how apocalypse and catastrophe differ from each other: the latter is an end without revelation, the former is an end that reveals some truth that was 'hidden in plain sight' (Williams 2011: 5). From the Disney store of films, then, Wall-E (2009) might stand as an example not of a catastrophic vision of the future but an apocalyptic one: the exhaustion of the Earth's resources and the re-appearance of organic life centuries later helps to reveal to the inhabitants of the spaceship, the Axiom, their true humanity, which lies not in screen-based interactions whilst their bodily needs are served by countless domestic robots, but in the hard toil of making anew human society down in the soil of the Earth. The closing sequence of the film, however, plays out like a repetition of what has gone before - a return to a normal state of affairs. Williams does not see it like that. Writing just two short but tumultuous years after the 2008 financial crash, he does not 
see a return to normality as being either possible or desirable. In his view then, the crisis the one through which we are still living - is a terminal one.

It was the proclamation of the era of austerity that loomed so large in our view when we as editors and contributors - first began to question prevailing images of futures (see also Bramall 2016, Bear 2015). Would it be the case that the next generation would do better than the last? Could we still sign up to the idea of progress? Could we entertain utopian visions of a future in which, somehow, human beings overcome their difficulties and find an alternative way of living that does not involve capitalism? In what ways might technologies - broadly understood - be entangled with such projects? Perhaps, to paraphrase Frederic Jameson (1982), it is easier to visualize the end of humanity than it is to imagine a significant change in capitalist relations? Or, to paraphrase Lauren Berlant (2011), perhaps contemporary neoliberal capitalism involves being stuck in an impasse or feedback loop where even our attachments to more optimistic futures are cruel?

At the same time, it seems imperative to hold on to and cultivate more hopeful engagements with the future. Les Back cautions against a 'tone of sociological writing that is often in a despairing or hopeless key' (2015), not least because it risks creating (if not, in Beradi's terms, performing) a sense of certainty in how things will turn out. Back takes issue with how hope becomes tied to futurity - as, for example, an imagination of, a deferral to, a faith in, or a projection into, the not-yet - proposing instead that a sociology of hope is both 'tuned to the conditions of the present', and, relatedly, is an empirical project (see also Coleman and Ferreday 2010). To the questions that we have posed so far then, we might add: who is the 'we' that becomes affiliated with dystopian or utopian visions of the future? Are different versions of the future possible or desirable for everyone? Indeed, we note as significant the Western focus of much social science research on the future, including this 
Special Issue. Barbara Adam and Chris Groves (2007) argue that innovation and progress become intertwined with the emergence of industrialisation and capitalism meaning that in Western societies in particular, the future becomes that which can and should be invested in, commodified and colonised. Such processes of making the future 'firm' (Uncertain Commons 2013) often assume that time is a neutral container that moves, inevitably, automatically and progressively, from past to present to future. However, such a conception of temporality is historically, socially and culturally specific, and has implications for how bodies become situated temporally and spatially. And, as Richard Tutton's paper explores, imaginations of the future exist not only in the mind but are also material - matter and meaning are entangled.

The processes by which the future is firmed also commonly involve technologically focused, technologically determinist, and industry oriented understandings of time and the promise of futurity, which as Sarah Kember (2016) argues, tend to involve disembodied and masculinist knowledge practices, which reproduce existing gender, sexual and racial inequalities. There is, then, a politics and ethics of and to temporality and the future, where futurity is actively involved in the making and re-making of difference and inequality. For example, Lisa Adkins examines how, far from emptying out futures as has been argued in social and cultural theory (e.g. by Maurizzio Lazzarato 2011), speculative finance - and especially speculative mortgages - produces an intensely active time, that engages feminine subjectivities in particular. Brown and Nettleton's paper analyses the mutually constitutive traffic between biology, law, and economics in political framings of anti-microbial resistance (AMR), showing how biological resistance is transformed into the political economy of markets through dystopian imaginations of the future. Further questions this special issue grapples with include how the present might become a means of creating 'an improvisation with a future not yet realised' (Back 2015)? What might cultivating such improvisations, 
unexpected opportunities, glitches or surprises involve? For Kember, creative writing is a practice that can queer the elisions of technologies, futurity and power; for the authors of some of the papers here, other strategies lend themselves to the task of critically engaging (with) the future so as to open up its possibilities. Mike Michael sees interdisciplinary speculative methods as particularly apposite for yielding futures, both Big and Little, while for Rebecca Coleman participatory, sensory methods and an attention to the affectivity of futurity indicate some means of intervening in and inventing worlds. Ben Anderson focuses on how emergencies are designated and articulated, and argues that shifting attention from the state to activism (in this case, the Black Lives Matter movement) enables a consideration of how temporality and futures are lived and experienced differently.

In addressing such questions, the special issue represents a renewed intellectual commitment to a rigorous interdisciplinary engagement with the future, working with ideas developed in the context of sociology, geography, philosophy and design, as well as through areas that cut across them, including science and technology studies, visual culture, feminist theory, queer theory, and cultural theory. The articles offer new conceptual framings for thinking about the future. These include: a recuperation of the idea of 'wicked futures' proposed by Ritte and Martin Webber (1973) (Tutton); an attention to how futures are understood and enacted on different scales (Michael); an unpacking of the significance of financial speculation to futurity (Adkins); a consideration of the sensory and intangible aspects of futurity (Coleman); an examination of how relations to futurity are organised and experienced through different speeds and senses of urgency (Anderson); and an analysis of the relationship between catastrophism, immunity and futurity (Brown and Nettleton). They also examine how particular ideas about and versions of the future are mobilized and contested in specific cases, such as securitized debt (Adkins), emergencies (Anderson), antibiotic resistance (Brown and Nettleton), participatory arts projects (Coleman), the 
public understanding of science (PUS) and public engagement with science and technology (PEST) (Michael), and in concepts and theories developed in sociology and STS (Tutton).

In this sense, the volume draws together work by an international group of scholars to further develop the terrain of an interdisciplinary social science of the future. The term 'terrain' is selected here purposefully to indicate both that we are attempting to map out a field of work that is, we suggest, in the process of being revitalised, and that we see this field as uneven: there are various ways in which 'the future' comes to be 'at stake' - socially, culturally, technologically, economically, politically - and that it can be oriented to, invested in, performed and made material. The contributions draw attention to existing theoretical and conceptual resources that may be taken up, developed and/or twisted to examine futurity. At the same time, they demonstrate the need for new theories, methods and practices to question the status, role and salience of the future today - in the words of Michael (this volume), to both set out 'a future for the sociology of the future' and treat this future as an analytical and empirical object. This special issue is thus not intended to be the last word in future studies, but rather it attempts to generate further debate.

\section{Acknowledgements}

This special issue emerges from the ESRC Research Seminar Series, Austerity Futures: Imagining and Materialising the Future in an 'Age of Austerity' (grant number ES/Jo21512/2). Many of those who were co-applicants of the grant and who participated in events are contributors to this volume; we thank them for their generosity and insightfulness. We would also like to thank others who participated in the series and conference, and especially: Michelle Bastian, Bron Szerszynski, Alex Wilkie, Michael Guggenheim, Nina Wakeford, John Urry, Joe Deville, Rebecca Bramall, Paul Martin, Julie 
Froud, Derek McCormack, Patricia Ticineto Clough, Barbara Adam, Yasmina Reggad,

Hazel Marsh, Yael Gerson, Vicki Dabrowski, Alice Corbel, Emma Dabiri, and Phil Thomas.

\section{Bibliography}

Adam, B. (1995) Timewatch: social analysis of time. Cambridge: Polity Press.

Adam, B. (1994) Time and social theory. Cambridge: Polity Press.

Adam, B., (2004a) 'Towards a New Sociology of the Future', unpublished paper, available at: http://www.cf.ac.uk/socsi/futures/newsociologyofthefuture.pdf.

Adam, B. (2004b) Time. Polity Key Concepts Series. Cambridge: Polity Press.

Adam, B. (2009) 'Futures in the making: sociological practice and challenge', in Jeffries, V. (ed.) Handbook of public sociology. Lanham, MD: Rowman \& Littlefield Publishers, pp. 429474.

Adam, B. (2010) 'Future Matters: Challenge for social theory and social inquiry', in Cultura e comunicazione 1, pp. 47-55.

Adam B, Groves C. (2007), Future Matters: Action, Knowledge, Ethics, Amsterdam: Brill Books. Adam, B. (2011), 'Wendell Bell and the Sociology of the Future: Challenges Past, Present and Future', Futures, 43(6):590-5.

Asimov, I. (1964) 'Visit to the World's Fair of 2014', The New York Times, 16 August 1964. Amoore, L., (2013) The Politics of Possibility: Risk and Security Beyond Probability. Durham and London: Duke University Press.

Anderson, B. (2009) 'Security and the future: anticipating the event of terror', Geoforum, 41: $227-235$.

Anderson, B. (2010) 'Preemption, precaution, preparedness: anticipatory action and future geographies', Progress in Human Geography, 34(6): 777-798. 
Back, L. (2015) 'Blind pessimism and the sociology of hope', Discover Sociology, available at: http://discoversociety.org/2015/12/01/blind-pessimism-and-the-sociology-of-

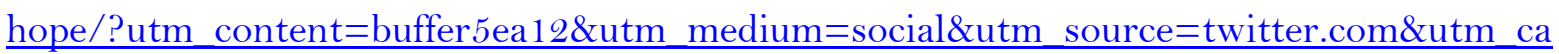
mpaign=buffer, accessed $21^{\text {st }}$ January 2016.

Bear, L. (2015) Navigating Austerity: Currents of Debt Along a South Asian River, Stanford: Stanford University Press.

Berardi FB., (2011), After the Future, G. Gensoko and N. Thoburn (eds), A. Bove, M. Cooper, E. Empson, Enrico, G. Mecchia and T. Terranova (trans), Edinburgh: AK Press.

Berlant, L. (2011) Cruel Optimism, Durham, NC and London: Duke University Press.

Brammal, R. (ed.) (2016) 'Austerity', special issue of New Formations, 87.

Brown, N., Rappert, B. and Webster, A. (eds.) (2000) Contested Futures: A Sociology of Prospective Techno-Science, Aldershot: Ashagate.

Brown N., Michael M., (2003), 'A Sociology of Expectations: Retrospecting Prospects and Prospecting Retrospects', Technology Analysis and Strategic Management, 15 (1): 3-18.

Clegg, N. (2011) Party Conference Speech, 21 September.

Clough, P. T. (2014) 'Beyond Neoliberalism: Bodies, Affect and Calculation', Keynote presentation, Futures in Question Conference, Goldsmiths, University of London, 11-12 ${ }^{\text {th }}$ September 2014. Available to listen to here:

http://www.austerityfutures.org.uk/conference/conference-keynote-recordings/ (accessed $28^{\text {th }}$ July 2016).

Clough, P.T., Gregory, K., Haber, B. and Scannell, R. J. (2015) ‘The Datalogical Turn’, in Vannini, P. (ed.) Non-Representational Methodologies: Re-envisioning Research, London: Routledge, pp. 146-164.

Fisher, M. (2014) Ghosts of my Life: Writings on Depression, Hauntology and Lost Futures, Hants: Zero Books.

Giroux, H. A. (2011) 'Fighting for the future: American youth and the struggle for 
democracy', Cultural Studies, Critical Methodologies, 1 1(4): 328-340.

International Forum of Sociology Third Forum (2016) 'The Futures we Want: Global Sociology and the Struggles for a Better World, Vienna.

Hansen, M. (2015) Feed Forward: On the Future of Twenty-First Century Media, Chicago:

Chicago University Press.

Jameson F., (1982), 'Progress versus Utopia; Or, Can We Imagine the Future? Science Fiction Studies, 9(2):147-58.

Lazzarato, M. (2011) The Making of Indebted Man, Amsterdam: Semiotexte.

Levitas R., (2011), The Concept of Utopia. London: Peter Lang.

Rittel, H.W. and Webber, M.M., (1973) 'Dilemmas in a General Theory of Planning', Policy Sciences, 4(2):155-69.Rose, N and C Novas (2005) 'Biological citizenship, in A. Oong and S. Collier (eds) Global Assemblages: Technology, Politics, and Ethics as Anthropological Problems, London: Blackwell.

Samuel, L (2007) The End of the Innocence: the 1964-1965 New York World's Fair, New York: University of Syracuse Press.

Schulz, M. S. (ed.) (2015) 'Future Moves in Culture, Society and Technology', special issue of Current Sociology, 63(2).

Urry, J. (2011) Climate Change and Society, Cambridge: Polity.

Urry, J. (2013) After Oil: Oil Dregs and Social Futures, London: Zed Books.

Urry, J. (2016) What is the Future? Cambridge: Polity.

Vaughan, A. (2015) 'Earth's climate entering new "permanent reality” as $\mathrm{CO} 2$ hits new high', The Guardian, $9^{\text {th }}$ November 2015 , available at:

http://www.theguardian.com/environment/2015/nov/09/earths-climate-entering-newpermanent-reality-as-co2-hits-new-high?CMP=share_btn_tw, accessed $21^{\text {st }}$ January 2016. Willetts, D. (2011) The Pinch: How the Baby Boomers Took Their Children's Future - And Why They Should Give It Back, Atlantic Books. 
Williams, E. C. (2011) Combined and Uneven Apocalypse, London: Zero Books.

World Meterological Association (2015) 'Greenhouse gas concentrations hit yet another record', Press Release 11, available at:

https://www.wmo.int/media/content/greenhouse-gas-concentrations-hit-yet-anotherrecord, accessed $21^{\text {st }}$ January 2016.

Žižek, S. (2011), Living in the End Times, London: Verso. 